DOI: https://doi.org/10.47405/mjssh.v6i9.999

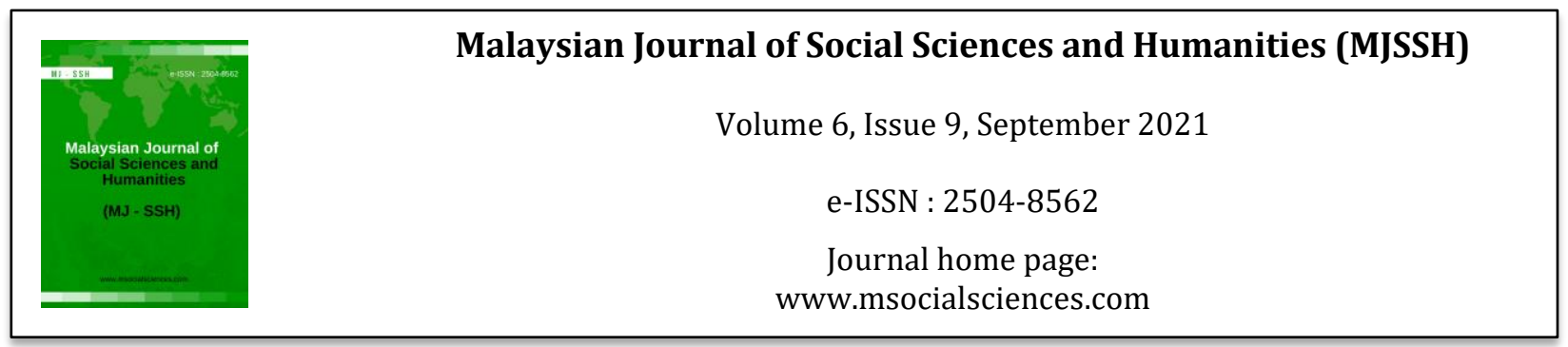

\title{
Tanggapan Golongan Miskin Bandar Berhubung Perintah Kawalan Pergerakan (PKP) di Kota Kinabalu, Sabah
}

\author{
Adi Jafar ${ }^{1}$, Fionna Geogre ${ }^{1}$, Nordin Sakke ${ }^{1}$, Mohammad Tahir Mapa ${ }^{1}$, Aisah Meri ${ }^{1}$, Abdul Hadi \\ Alimuddin1, Molia Sebi Dinggai1 \\ 1Universiti Malaysia Sabah (UMS)
}

Correspondence: Nordin Sakke (dinums@ums.edu.my)

\begin{abstract}
Abstrak
Masyarakat berpendapatan rendah merupakan golongan yang rentan atau mudah terancam (vulnerable) ketika berhadapan dengan bahaya (hazard). Wabak Novel Koronavirus atau COVID-19 merupakan salah satu contoh bahaya semula jadi yang dikategorikan sebagai pandemik dan telah menular ke serata dunia termasuklah Malaysia. Berikutan penularan wabak COVID-19 yang berlaku dengan pantas di seluruh dunia menyebabkan Malaysia mengambil langkah berjaga-jaga dengan melaksanakan perintah kawalan pergerakan (PKP). Tujuannya adalah bagi mengekang berlakunya penularan wabak COVID19 di dalam negara. Walau bagaimanapun, perlaksanaan PKP telah merubah pola kehidupan harian masyarakat secara umumnya khususnya kepada golongan berpendapatan rendah. Oleh hal demikian, kajian ini ingin mengenal pasti tanggapan masyarakat berpendapatan rendah berstatus B40 di Bandaraya Kota Kinabalu terhadap kesan pelaksanaan PKP berdasarkan sektor pekerjaan. Kajian ini menggunakan kaedah survei (soal selidik) dalam proses pengutipan data di lapangan. Dalam proses survei yang dilakukan, seramai 93 orang responden berstatus golongan B40 berjaya ditemu bual. Data yang diperoleh melalui kaedah survei tersebut telah dianalisis menggunakan analisis frekuensi, analisis tabulasi silang dan analisis skor min. Kajian ini mendapati golongan B40 beranggapan pelaksanaan PKP memberi kesan ke atas kehidupan mereka terutamanya daripada aspek ekonomi, keselamatan, kesihatan dan hubungan sosial. Kumpulan bekerja sendiri merupakan golongan yang paling terkesan mengalami masalah daripada aspek ekonomi. Salah satunya adalah wujud fenomena pengangguran sementara dalam kalangan bekerja sendiri. Walaupun begitu, perlaksanaan PKP didapati memberi impak positif terhadap aspek keselamatan, kesihatan dan hubungan sosial golongan B40 di Bandaraya Kota Kinabalu, Sabah.
\end{abstract}

Kata kunci: golongan berpendapatan rendah, Perintah Kawalan Pergerakan (PKP), Bandaraya Kota Kinabalu, sektor pekerjaan

\section{Perception among Urban Poor Towards the Movement Control Order (MCO) in Kota Kinabalu, Sabah}

\begin{abstract}
The low-income community is a group of people who are likely to be more vulnerable and easily threatened by any kind of hazard. The Novel Outbreak of Coronavirus also known as COVID-19 which is also categorized as a pandemic in an example of this natural hazard mentioned, has spread all over the world, including Malaysia. The rapid spread of COVID-19 globally has cause Malaysia to take precautionary measures by implementing Perintah Kawalan Pergerakan (PKP). The purpose of
\end{abstract}


implementing such measures is to stem the spread of COVID-19 within the country. However, the implementation of PKP generally has transformed the daily pattern of the people specifically for the low-income community. Therefore, the aim of this study is to identify the perception of the lowincome community with the status of B40 regarding the impact of PKP implementation towards the employment sector. This study uses survey method (questionnaires) for the process of data collection on the field. There were 93 respondent whom were from the B40 group that was interviewed during the data collection process. The data obtained through the survey method was then analyzed using frequency analysis, cross-tabulation analysis and mean score analysis. The study found that the lowincome community with the B40 status thinks that the implementation of PKP does affects their lives mainly from economic, safety, health and social aspects. Besides that, the study also shows that the self-employed group is heavily affected in the economy aspect. This is because temporary unemployment phenomenon exists during the implementation of PKP. However, the implementation of PKP was also found to have a positive impact on the aspects of safety, health and social relations among the B40 group in Kota Kinabalu, Sabah.

Keywords: iow income community, perintah kawalan pergerakan (PKP), Kota Kinabalu City, Employment sector

\section{Pengenalan}

Manusia di muka bumi ini amat terdedah dengan pelbagai bentuk bahaya (hazard) termasuklah bahaya semula jadi, bahaya teknologi dan bahaya degradasi alam sekitar (Tarbotton et al., 2015; Jafar et al., 2021a). Bahaya semula jadi dapat dikelaskan kepada tiga kategori merangkumi bahaya hidrometeorologi, bahaya geofizikal dan bahaya biologi (Dickson et al., 2012). Wabak Novel Koronavirus atau COVID-19 merupakan salah satu contoh bahaya semula jadi yang dikategorikan sebagai pandemik (Mameli, 2019; WHO, 2019; Jafar et al., 2021b). Terma atau istilah pandemik digunakan apabila berlakunya penularan patogen ke atas manusia dalam jumlah populasi dan skala geografi yang besar (Rhyddhi, 2015). Wabak COVID-19 dikategorikan sebagai pandemik disebabkan penularannya yang sangat meluas. Dalam tempoh lebih kurang lapan bulan selepas kes pertama jangkitan COVID-19 dikesan, seramai lebih 19 juta orang di seluruh dunia telah dijangkiti virus tersebut dan 700 ribu daripadanya telah disahkan meninggal dunia (BH Online, 2020).

Pandemik COVID-19 bermula daripada penularan wabak ini di peringkat epidemik yang merebak secara meluas sehingga tidak dapat dikawal dan menyebabkan kematian dalam masa singkat. Kes jangkitan pertama dikesan di Bandaraya Wuhan, Hubei, China pada pertengahan bulan Disember 2019. Pada tanggal 10 Februari tahun 2020, sekurang-kurangnya masing-masing sebanyak 40, 261 kes jangkitan dan 909 kes kematian akibat COVID-19 telah disahkan berlaku di China (Jun She et al., 2020). Rentetan daripada penularan wabak COVID-19 yang berlaku dengan pantas di China menyebabkan banyak negara mengambil langkah berjaga-jaga bagi mengekang penularan wabak tersebut termasuklah Malaysia. Kerajaan Malaysia sendiri telah mengisytiharkan perintah kawalan pergerakan (PKP) selama 42 hari iaitu bermula pada tanggal 18 Mac 2020 hingga 28 April 2020 (Perutusan khas Perdana Menteri, 2020) bagi mengekang penularan wabak tersebut di peringkat dalam negara.

Umumnya, perlaksanaan PKP walaupun dalam kerangka tujuan untuk mengekang penularan wabak COVID-19 daripada terus merebak namun secara tidak langsung mendatangkan implikasi negatif kepada penduduk khususnya daripada aspek sosioekonomi (Jabatan Perangkaan Malaysia, 2020). Dalam tempoh perlaksanaan PKP, kebanyakan premis kerajaan dan swasta tidak dibenarkan beroperasi kecuali bagi sektor perkhidmatan utama negara seperti kesihatan dan keselamatan, telekomunikasi, peruncitan, kewangan dan pengangkutan (Majlis Keselamatan Negara, 2020). Selain itu, masa operasi bagi beberapa sektor perkhidmatan juga dipendekkan kepada lapan hingga 10 jam sahaja. Di Sabah misalnya, had masa beroperasi bagi premis peruncitan, perkilangan, stesen minyak, pasar raya, restoran, pasar awam dan perkhidmatan penghantaran dipendekkan sehingga tidak melebihi pukul 6.00 petang (Noor Fzlinda et al., 2020). 
Keadaan ini sedikit sebanyak memberi kesan kepada penduduk. Akibat daripada penutupan dan pengurangan tempoh masa operasi beberapa jenis premis sepanjang tempoh PKP menyebabkan ramai penduduk hilang pekerjaan dan sumber pendapatan selain daripada hasil jualan berkurang (Jabatan Perangkaan Malaysia, 2020). Dalam sektor pertanian misalnya, pekebun kecil mengalami masalah terputus pendapatan harian. Hal ini berpunca daripada rantaian pengagihan yang terjejas disebabkan oleh penutupan operasi sektor sokongan, ketiadaan pekerja dan kemerosotan rizab tunai (Dzulkifli, 2020). Tidak sekadar itu, perlaksanaan PKP juga berpotensi menyebabkan berlakunya gangguan tekanan mental, emosi dan masalah obesiti (Jabatan Perangkaan Malaysia, 2020). Perkara yang hampir sama juga dihadapi oleh kebanyakan negara lain yang melaksanakan perintah darurat atau kuarantin bagi mengekang penularan wabak COVID-19. Perlaksanaan perintah darurat didapati memberi kesan terhadap perlakuan dan psikologi manusia seperti stres, gemuruh dan kemurungan (Ghani, 2020).

Oleh hal demikian, makalah ini bertujuan untuk mengenal pasti tanggapan masyarakat berpendapatan rendah di Bandaraya Kota Kinabalu terhadap kesan perlaksanaan PKP. Ini kerana, masyarakat berpendapatan rendah merupakan golongan yang lebih rentan atau mudah terancam ketika berhadapan dengan satu-satu bahaya berbanding golongan berpendapatan tinggi (Wika, 2012).

\section{Sorotan Literatur}

Movement Control Order (MCO) boleh diertikan dalam konteks atau skop yang lebih luas. Di Itali perlaksanaan MCO diterjemahkan dalam bentuk tindakan penjarakan fizikal, kuarantin dan pengasingan (Giallonardo et al., 2020). Fahim (2020) pula menggunakan istilah penjarakan sosial yang boleh diterjemahkan sebagai kaedah untuk meminimumkan interaksi orang ramai bagi mencegah terjadinya penyebaran virus COVID-19. Berbeza dengan Naomie et al. (2020) yang menggunakan istilah "lockdown" dalam menjelaskan langkah-langkah yang digunakan oleh kerajaan Malaysia untuk mengekang penyebaran wabak melalui perlaksanaan MCO. Walaupun istilah yang digunakan adalah berbeza, secara umumnya ia menerangkan tentang satu tujuan yang sama iaitu membatasi atau mengawal pergerakan secara fizikal. Perkara yang membezakan hanyalah daripada segi tahap kawalan pergerakan tersebut. Di Malaysia, istilah yang digunakan bagi menggambarkan Movement Control Order (MCO) adalah perintah kawalan pergerakan (PKP). Di Malaysia, kawalan pergerakan dikelaskan kepada tiga peringkat iaitu PKP, PKP Bersyarat (PKPB) dan PKP pemulihan (PKPP) (Laman Rasmi Pejabat Perdana Menteri, 2020). Namun demikian, tahap kawalan pergerakan yang paling ketat adalah pada peringkat PKP.

Perlaksanaan PKP sememangnya mempunyai pro dan kontra yang tersendiri. Secara umumnya ia boleh dilihat daripada dua sisi pandang yang berbeza iaitu secara positif dan secara negatif. Daripada sisi pandang positif, PKP dilihat berjaya mengurangkan kadar jangkitan wabak COVID-19. Buktinya, jumlah kes jangkitan COVID-19 di Malaysia semasa tempoh perlaksanaan PKP menunjukkan tren yang menurun (Naomie et al., 2020). Situasi yang sama juga berlaku di Indonesia. Perebakan wabak COVID-19 berjaya dikurangkan melalui perlaksanaan lockdown (Nor Rohim \& Annissa, 2020). Kesan positif lain daripada perlaksanaan PKP juga didapati dapat mengurangkan pencemaran alam sekitar sama ada dalam konteks pencemaran air sungai (Siti Maslina, 2020) mahupun pencemaran udara (Mohd Shahrul et al., 2020; Nor Rohim \& Annisa, 2020). Dalam masa yang sama, perlaksanaan MCO atau PKP juga didapati berjaya meningkatkan celik IT dalam kalangan petani, penternak, nelayan dan pekebun terutamanya daripada aspek pemasaran produk (Siti Zakiah, 2020).

Daripada sisi negatifnya pula, perlaksanaan MCO didapati menyebabkan sektor ekonomi terganggu terutamanya kepada sektor ekonomi tidak formal (International Labour Organization, 2020; Estro, 2020) khususnya daripada aspek pasaran buruh. Impak ketara rentetan situasi tersebut adalah berlakunya pengangguran dalam skala yang besar (Kasim, 2020; Estro, 2020). Selain itu, berlaku juga pengurangan terhadap jumlah pendapatan bulanan. Golongan bekerja sendiri merupakan entiti yang paling terkesan mengalami pengurangan jumlah pendapatan (Jabatan Perangkaan Malaysia, 2020) termasuklah dalam sektor pertanian. Lambakan sayur-sayuran terpaksa dibuang berikutan ketiadaan pembeli. Hal ini terjadi disebabkan berlakunya kesalahfahaman antara jaringan pembekal dan 
pengedar berikutan semua aktiviti pengangkutan penghantaran hasil pertanian telah terhenti pada Fasa 1 PKP (Siti Zakiah, 2020).

Golongan masyarakat yang paling terdedah terhadap kesan negatif pandemik ini adalah komuniti miskin bandar (Puteri Marjan \& Theebalakshmi, 2020) yang tergolong dalam status B40 (Serina, 2020). Selain berhadapan dengan kos sara hidup yang tinggi, jenis pekerjaan sebahagian besar komuniti ini juga menuntut mereka untuk hadir secara fizikal di tempat kerja. Kegagalan berbuat demikian akan mengganggu sumber ekonomi mereka. Dalam tempoh PKP juga, perniagaan berskala perbadanan perusahaan kecil dan sederhana (PKS) telah mengalami gangguan daripada aspek operasi, aliran tunai, akses kepada pakej rangsangan, rantaian bekalan, mengalami risiko muflis dan mengalami masalah meramalkan arah perniagaan pada masa hadapan (Ahmad Raflis, 2020). Antara lainnya, perlaksanaan PKP juga mendatangkan kesan buruk terhadap kesihatan mental khususnya menyebabkan kekecewaan, kemurungan, kebimbangan tentang masa depan, kegelisahan dan gangguan tekanan pasca-trauma (Giallonardo et al., 2020).

\section{Metod Kajian}

Kajian ini tertumpu di Bandaraya Kota Kinabalu yang terletak di daerah Kota Kinabalu, Sabah. Daerah Kota Kinabalu yang merupakan ibu negeri Sabah terletak di Pantai Barat Sabah. Kedudukan daerah Kota Kinabalu terletak di latitud $5^{\circ} 56^{\prime}$ Utara dan longitud $116^{\circ} 03^{\prime}$ Timur. Daerah Kota Kinabalu mempunyai saiz keluasan $351 \mathrm{~km}^{2}$ iaitu 0.5 peratus daripada jumlah keseluruhan Negeri Sabah. Pada tahun 2000 jumlah penduduk Kota Kinabalu seramai 372,042 orang dan meningkat kepada 462,963 pada tahun 2010 (Jabatan Perangkaan Malaysia, Negeri Sabah, 2015). Tiga tahun kemudian iaitu pada tahun 2017 populasi penduduk Kota Kinabalu berjumlah 553, 4 Ribu (Utusan Borneo Online, 2017). Daerah Kota Kinabalu boleh dibahagikan kepada beberapa kawasan seperti Bandaraya Kota Kinabalu, Tanjung Aru, Kuala Inanam, Kota Kinabalu Nountun, Menggatal, Menggatal North, Kota Kinabalu Industrial Park (KKIP), Kuala Menggatal dan Telipok (Jabatan Perangkaan Malaysia, 2007). Walaupun begitu, fokus kajian ini adalah di kawasan bandar raya Kota Kinabalu.

\section{Rajah 1: Daerah Kota Kinabalu}

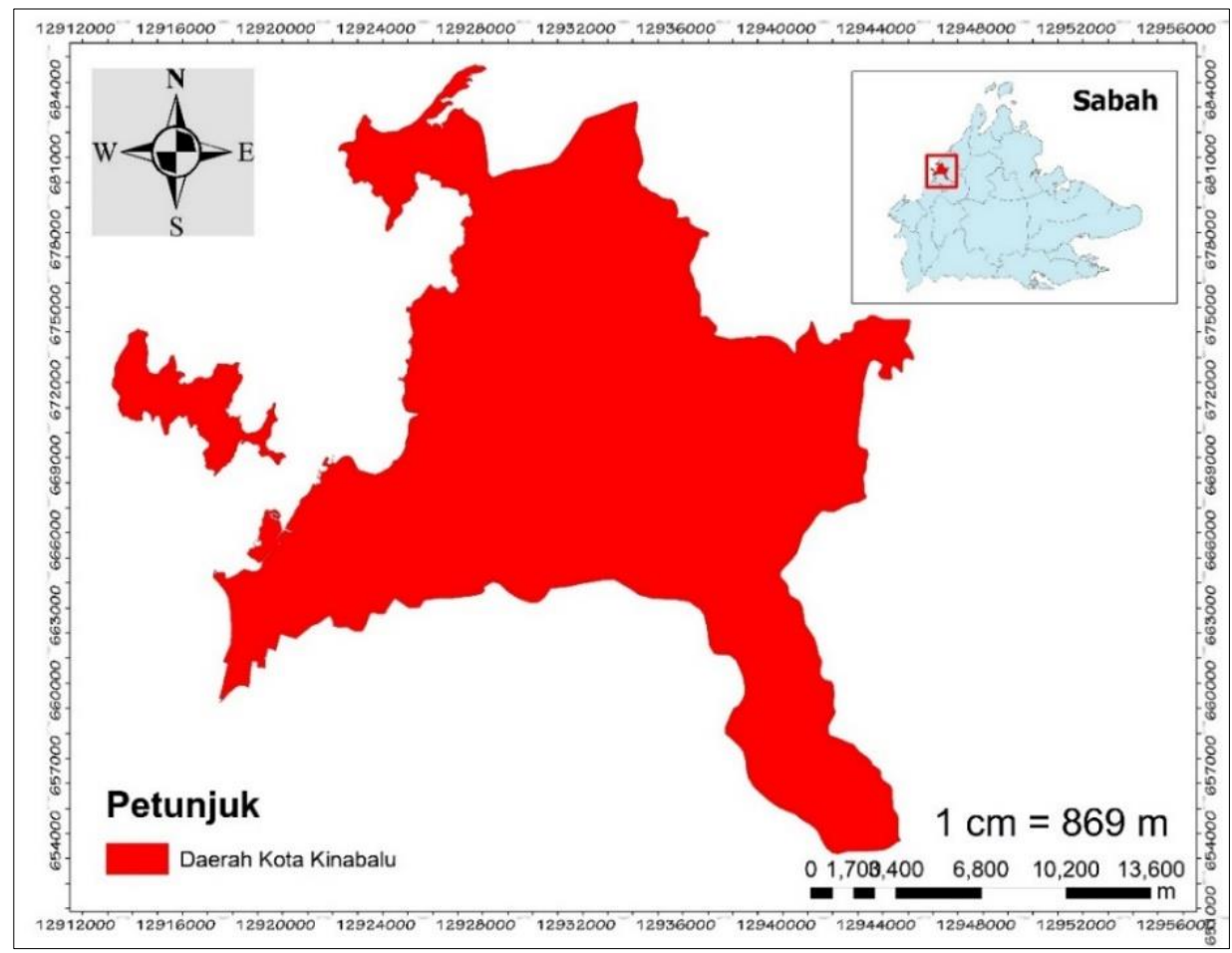

Sumber: Diubahsuai dari Jabatan Ukur dan Pemetaan Malaysia (2011) 
Kajian ini menggunakan pendekatan kuantitatif bagi menjawab objektif yang telah dibentuk. Oleh hal demikian, kaedah survei melalui penggunaan instrumen soal selidik diguna pakai untuk menilai tanggapan masyarakat berpendapatan rendah di daerah Kota Kinabalu terhadap kesan perlaksanaan PKP. Responden adalah dalam kalangan penduduk yang tinggal dalam lingkungan kawasan Bandaraya Kota Kinabalu. Reka bentuk soalan dalam kajian ini adalah daripada jenis soalan tertutup (closed ended). Penggunaan soalan jenis tertutup pada borang soal selidik adalah atas alasan dapat menjimatkan masa responden menjawab soalan. Selain itu, soalan jenis tertutup juga lebih mudah untuk dijawab, jawapan mudah dikodkan untuk dianalisis dan seterusnya memudahkan perbandingan data dilakukan.

Dalam kajian ini, penentuan sampel dilakukan menggunakan teknik pensampelan bertujuan (purposive sampling). Sampel yang dipilih hanya dalam kalangan golongan masyarakat yang berpendapatan rendah. Menurut Chamhuri Siwar et al. (2019), kelas pendapatan isi rumah boleh dibahagikan kepada tiga kumpulan iaitu B40, M40 dan T20. Di antara ketiga-tiga kelas pendapatan tersebut, B40 tergolong dalam kumpulan pendapatan yang paling rendah dengan julat pendapatan isi rumah berjumlah RM4,360 dan ke bawah (Laporan Penyiasatan Perbelanjaan Isi rumah, 2016). Oleh itu, responden yang ditemu bual dalam kajian ini adalah penduduk yang mempunyai pendapatan isi rumah kurang daripada RM4361. Sebanyak 93 puluh set borang soal selidik berjaya diedarkan dalam kajian ini. Menurut Bailey (1978) dan Er et al. (2013), saiz sampel yang diperlukan untuk ujian statistik minimumnya adalah seramai tiga puluh orang responden. Oleh itu, jumlah sampel sebanyak 93 set yang digunakan dalam kajian ini telah pun memenuhi syarat minima jumlah sampel yang diperlukan. Soalan instrumen soal selidik yang digunakan dalam kajian ini diadaptasi daripada Newsletter Jabatan Perangkaan Malaysia (2020).

Sebelum proses kutipan data soal selidik dilakukan sepenuhnya, terlebih dahulu dijalankan kajian rintis untuk menguji tahap kebolehpercayaan instrumen yang digunakan. Dalam kajian rintis tersebut sebanyak 30 set borang soal selidik berjaya diedarkan dan dianalisis menggunakan analisis Cronbach Alpha. Jadual 1 menunjukkan nilai Cronbach Alpha yang diperoleh berdasarkan tema dalam borang soal selidik. Dapatan Ketiga-tiga tema menunjukkan nilai Cronbachs Alpha adalah melebihi 0.6. Menurut Viratna (2015), nilai Cronbach Alpha yang melebihi 0.6 dikategorikan sebagai nilai yang mempunyai tahap kebolehpercayaan yang tinggi.

Jadual 1: Nilai Cronbach Alpha kajian rintis

\begin{tabular}{lcc}
\hline Pernyataan Tema & Cronbachs Alpha & Bilangan Item \\
\hline Kesan kepada keselamatan dan kesihatan & 0.626 & 5 \\
\hline Kesan daripada aspek hubungan sosial & 0.682 & 6 \\
\hline Reaksi Mengenai Aspek Kebajikan & 0.805 & 5 \\
\hline Purata (Cronbach Alpha) & 0.704 & 16 \\
\hline
\end{tabular}

Data mentah yang diperoleh melalui kaedah survei seterusnya akan dianalisis menggunakan perisian SPSS Windows Version 20. Teknik analisis yang diaplikasikan dalam kajian ini merangkumi analisis frekuensi, analisis tabulasi silang (crosstab) dan analisis skor min. Teknik analisis frekuensi diguna pakai untuk menjelaskan demografi responden manakala analisis tabulasi silang berfungsi untuk menerangkan perkaitan antara dua pemboleh ubah iaitu sektor pekerjaan dan kesan perlaksanaan PKP. Analisis skor min pula digunakan untuk menilai kesan PKP daripada aspek kebajikan, kesihatan dan hubungan sosial berdasarkan kepada soalan yang diperoleh dalam bentuk skala likert. Nilai skor min diukur berdasarkan tiga tahap pengelasan iaitu rendah (bagi nilai skor 1.00 sehingga 2.33), sederhana (bagi nilai skor 2.34 sehingga 3.67) dan tinggi (bagi nilai skor 3.68 sehingga 5.00) (Abdullah et al., 2017; Noorazuan \& Shamsuddin, 2018).

\section{Dapatan Kajian}

\section{Latar Belakang Responden}


Responden yang ditemu bual dalam kajian ini sebahagian besarnya adalah terdiri daripada kaum lelaki (60.2\%). Kebanyakan responden berumur dalam lingkungan 20 hingga 40 tahun (74.2\%). Majoriti responden yang ditemui adalah berbangsa Bajau (33.3\%), Kadazan/Dusun (29\%) dan Bugis (12.9\%). Selebihnya lagi berbangsa Melayu Brunei (7.5\%), Suluk (4.4\%) dan lain-lain (rujuk Jadual 2). Daripada segi status perkahwinan pula adalah hampir seimbang antara responden yang telah berkahwin $(55.9 \%)$ dan belum berkahwin $(44.1 \%)$. Hampir dua pertiga $(67.7 \%)$ daripada jumlah keseluruhan responden mempunyai bilangan isi rumah kurang daripada enam orang. Sebanyak satu pertiga lagi (32.3\%) mempunyai bilangan isi rumah lebih daripada enam orang. Terdapat tiga kategori pekerjaan utama responden iaitu kakitangan kerajaan (33.3\%), kakitangan swasta (33.3\%) dan bekerja sendiri (33.3\%). Kesemua responden yang bekerja dalam sektor kerajaan mempunyai pendapatan dalam lingkungan RM 1201 hingga RM 4360. Responden yang berpendapatan kurang daripada RM 1200 hanya daripada sektor swasta (11\%) dan bekerja sendiri (14\%).

Jadual 2: Latar belakang Responden

\begin{tabular}{lll}
\hline Item & Kategori & Peratus (\%) \\
\hline Jantina & Lelaki & 60.2 \\
& Perempuan & 39.8 \\
Umur & <20 & 14 \\
& $20-40$ & 74.2 \\
Suku & Melayu Brunei & 11.8 \\
& Kadazan/Dusun & 7.5 \\
& Bajau & 29 \\
& Bisaya & 33.3 \\
& Bugis & 2.2 \\
& Suluk & 12.9 \\
& Iranun & 4.4 \\
Jawa & 3.3 \\
Status Perkahwinan & Kagayan & 1.1 \\
Bilangan isi rumah & Toraja & 3.2 \\
& Murut & 2.2 \\
Status pekerjaan & Berkahwin & 1.1 \\
& 1 - 5 & 44.1 \\
Jumlah pendapatan & 6 - 10 & 55.9 \\
berdasarkan sektor & Kakitangan kerajaan & 67.7 \\
pekerjaan & Kakitangan swasta & 32.3 \\
& Bekerja sendiri & 33.3 \\
& Kerajaan: < RM 1200 & 33.3 \\
& Kerajaan: RM 1201- RM 4360 & 33.3 \\
& Swasta: < RM 1200 & 0 \\
& Swasta: RM 1201- RM 4360 & 33 \\
& B. Sendiri: < RM 1200 & 11 \\
& B. Sendiri: RM 1201- RM 4360 & 23 \\
& & 14 \\
& & 19 \\
\hline
\end{tabular}

\section{Persepsi Golongan B40 Terhadap Perlaksanaan PKP}

Berdasarkan Jadual 3 jelas menunjukkan bahawa golongan B40 secara umumnya setuju dengan perlaksanaan PKP, terutamanya yang bekerja dalam sektor kerajaan (4.58). Hal ini digambarkan melalui reaksi positif yang diberikan oleh kebanyakan kakitangan semua sektor pekerjaan (4.39). Kajian ini juga mendapati golongan B40 yang bekerja sebagai kakitangan kerajaan dan kakitangan swasta berpuas hati dengan bantuan yang diberikan semasa dalam tempoh perlaksanaan PKP. Hanya golongan bekerja sendiri yang kurang berpuas hati terhadap penerimaan bantuan yang diberikan. Selain itu, golongan B40 berstatus bekerja sendiri juga merupakan kumpulan yang paling terkesan 
mengalami kerugian ekonomi akibat perlaksanaan PKP. Kumpulan ini bersetuju bahawa perlaksanaan PKP telah menyebabkan sumber ekonomi mereka terganggu. Perkara yang sama juga berlaku pada kakitangan kerajaan dan kakitangan swasta. Walau bagaimanapun, darjah gangguan yang diterima oleh kedua sektor tersebut adalah lebih ringan berbanding bekerja sendiri. Secara keseluruhannya, dapatlah dirumuskan bahawa kakitangan kerajaan adalah kumpulan yang paling menunjukkan reaksi positif (3.95) terhadap perlaksanaan PKP.

Jadual 3: Persepsi Umum Perlaksanaan PKP berdasarkan sektor pekerjaan

\begin{tabular}{llllll}
\hline Bil & \multicolumn{1}{c}{ Pernyataan } & \multicolumn{3}{c}{ Nilai Min } \\
\cline { 3 - 5 } & Kerajaan & Swasta & $\begin{array}{c}\text { Bekerja } \\
\text { sendiri }\end{array}$ & $\begin{array}{c}\text { Semua } \\
\text { sektor }\end{array}$ \\
\hline 1 & Setuju dengan perlaksanaan PKP & 4.58 & 4.23 & 4.35 & 4.39 \\
2 & $\begin{array}{l}\text { Berpuas hati dengan bantuan } \\
\text { semasa PKP }\end{array}$ & 4.13 & 4.06 & 3.45 & 3.88 \\
3 & $\begin{array}{l}\text { PKP tidak mengganggu sumber } \\
\text { ekonomi }\end{array}$ & 3.13 & 2.58 & 1.84 & 2.52 \\
$\begin{array}{l}\text { Jumlah (min) } \\
\text { Jumlah sampel (n) }\end{array}$ & 3.95 & 3.62 & 3.21 & 3.60 \\
& 31 & 31 & 31 & 93
\end{tabular}

Petunjuk: Reaksi negatif (1.00 sehingga 2.33), reaksi neutral (2.34 sehingga 3.67), reaksi positif (3.68 sehingga 5.00)

Dari aspek keselamatan dan kesihatan, rata-rata golongan berstatus B40 bersetuju bahawa perlaksanaan PKP mampu untuk mengurangkan penularan virus COVID-19. Golongan ini juga beranggapan bahawa mudah untuk mendapat rehat yang secukupnya semasa perlaksanaan PKP terutamanya bagi kakitangan swasta (4.13) dan bekerja sendiri (4.10). Tidak hanya kesan positif, perlaksanaan PKP juga didapati mendatangkan impak negatif daripada aspek kesihatan. Dapatan menunjukkan semasa PKP dijalankan, golongan B40 cenderung mengalami tekanan emosi (stres) kecuali bagi kakitangan swasta. Selain itu, perlaksanaan PKP juga didapati meningkatkan lagi kebarangkalian untuk berlakunya obesiti terutamanya bagi responden yang bekerja sebagai kakitangan kerajaan. Antara lainnya, golongan B40 berpendapat bahawa tidak begitu mudah untuk melakukan aktiviti senaman semasa dalam tempoh perlaksanaan PKP (rujuk Jadual 4).

Jadual 4: Kesan Perlaksanaan PKP Terhadap Aspek keselamatan dan Kesihatan Berdasarkan Sektor Pekerjaan

\begin{tabular}{|c|c|c|c|c|c|}
\hline \multirow[t]{2}{*}{ Bil } & \multirow[t]{2}{*}{ Pernyataan } & \multicolumn{4}{|c|}{ Nilai Min } \\
\hline & & Kerajaan & Swasta & $\begin{array}{c}\text { Bekerja } \\
\text { sendiri }\end{array}$ & $\begin{array}{l}\text { Semua } \\
\text { sektor }\end{array}$ \\
\hline 1 & $\begin{array}{l}\text { Dapat kurangkan penularan virus } \\
\text { COVID-19 }\end{array}$ & 4.58 & 4.71 & 4.68 & 4.66 \\
\hline 2 & Kurangkan tekanan emosi & 3.39 & 3.87 & 3.10 & 3.45 \\
\hline 3 & Kurangkan Obesiti & 2.77 & 2.93 & 2.84 & 2.85 \\
\hline 4 & Dapat rehat yang cukup & 3.81 & 4.13 & 4.10 & 4.01 \\
\hline 5 & Dapat bersenam dengan mudah & 3.16 & 3.32 & 3.52 & 3.33 \\
\hline \multirow{2}{*}{\multicolumn{2}{|c|}{$\begin{array}{l}\text { Jumlah (min) } \\
\text { Jumlah sampel (n) }\end{array}$}} & 3.54 & 3.79 & 3.65 & 3.66 \\
\hline & & 31 & 31 & 31 & 93 \\
\hline
\end{tabular}

Petunjuk: Reaksi negatif (1.00 sehingga 2.33), reaksi neutral (2.34 sehingga 3.67), reaksi positif (3.68 sehingga 5.00)

Berdasarkan Jadual 5, didapati dengan melaksanakan PKP mampu memberi kesan positif terhadap aspek hubungan sosial. Ini kerana, golongan B40 berpendapat bahawa mereka mempunyai masa yang lebih panjang bersama keluarga (4.54) ketika dalam fasa PKP. Selain daripada itu, perlaksanaan PKP juga memudahkan golongan tersebut untuk beribadah bersama keluarga (4.45). Komunikasi secara maya juga dapat ditingkatkan pada masa itu (4.21). Perkara yang lebih menarik apabila kajian ini 
DOI: https://doi.org/10.47405/mjssh.v6i9.999

mendapati perlaksanaan PKP mampu untuk mengurangkan kadar jenayah setempat (4.05). Hal yang tidak kurang pentingnya juga apabila perpaduan dalam kalangan komuniti terutamanya dalam konteks kakitangan swasta dapat ditingkatkan semasa tempoh PKP. Walau bagaimanapun, golongan B40 tidak begitu setuju (bersikap neutral) bahawa kesan perlaksanaan PKP mampu untuk meningkatkan kadar kelahiran. Sekiranya dibandingkan berdasarkan sektor pekerjaan, didapati kakitangan swasta menunjukkan nilai min yang paling tinggi (3.52) bersetuju bahawa PKP mampu untuk meningkatkan kadar kelahiran. Secara umumnya, kajian ini mendapati sebahagian besar responden (4.08) berpendapat PKP memberi kesan positif terhadap aspek hubungan sosial.

Jadual 5: Kesan Positif Perlaksanaan PKP Daripada Aspek Hubungan Sosial Berdasarkan Sektor Pekerjaan

\begin{tabular}{|c|c|c|c|c|c|}
\hline \multirow[t]{2}{*}{ Bil } & \multirow[t]{2}{*}{ Pernyataan } & \multicolumn{4}{|c|}{ Nilai Min } \\
\hline & & Kerajaan & Swasta & $\begin{array}{c}\text { Bekerja } \\
\text { sendiri }\end{array}$ & $\begin{array}{l}\text { Semua } \\
\text { sektor }\end{array}$ \\
\hline 1 & $\begin{array}{l}\text { Mempunyai masa terluang lebih } \\
\text { lama bersama keluarga }\end{array}$ & 4.52 & 4.52 & 4.58 & 4.54 \\
\hline 2 & Dapat beribadah bersama keluarga & 4.39 & 4.48 & 4.48 & 4.45 \\
\hline 3 & Tingkatkan komunikasi alam maya & 4.16 & 4.19 & 4.29 & 4.21 \\
\hline 4 & Kadar jenayah setempat berkurang & 3.87 & 3.87 & 4.42 & 4.05 \\
\hline 5 & $\begin{array}{l}\text { Tingkatkan perpaduan dalam } \\
\text { kalangan komuniti setempat }\end{array}$ & 3.94 & 4.00 & 3.97 & 3.97 \\
\hline 6 & Pertambahan bilangan kelahiran & 3.10 & 3.52 & 3.13 & 3.25 \\
\hline \multicolumn{2}{|c|}{ Jumlah (min) } & 4.0 & 4.10 & 4.15 & 4.08 \\
\hline \multicolumn{2}{|c|}{ Jumlah sampel (n) } & 31 & 31 & 31 & 93 \\
\hline
\end{tabular}

Petunjuk: Reaksi negatif (1.00 sehingga 2.33), reaksi neutral (2.34 sehingga 3.67), reaksi positif (3.68 sehingga 5.00)

\section{Tahap ketersampaian bantuan kebajikan kepada golongan B40 semasa perlaksanaan PKP}

Jadual 6 menunjukkan reaksi Golongan B40 mengenai aspek kebajikan semasa tempoh PKP dijalankan. Didapati, sebahagian besar daripada golongan tersebut memperoleh bantuan tunai daripada pihak kerajaan terutamanya yang bekerja sebagai kakitangan kerajaan (4.03). Dalam erti lain, tahap ketersampaian bantuan tunai kepada golongan B40 daripada pihak kerajaan adalah tinggi (3.86). Selain daripada bantuan tunai yang diberikan oleh pihak kerajaan, golongan tersebut juga menerima bantuan derma daripada pihak luar (swasta dan orang persendirian). Walau bagaimanapun, tidak semua responden berpeluang untuk mendapatkan bantuan derma daripada pihak luar. Ini kerana, didapati hanya hampir separuh (2.98) daripada jumlah keseluruhan responden yang ditemu bual berpeluang menerima bantuan tersebut.

Jadual 6: Reaksi Golongan B40 Semasa fasa PKP Mengenai Aspek Kebajikan

\begin{tabular}{llllll}
\hline Bil & \multicolumn{1}{c}{ Pernyataan } & \multicolumn{4}{c}{ Nilai Min } \\
\cline { 3 - 5 } & Kerajaan & Swasta & $\begin{array}{c}\text { Bekerja } \\
\text { sendiri }\end{array}$ & $\begin{array}{c}\text { Semua } \\
\text { sektor }\end{array}$ \\
\hline 1 & Dapat bantuan tunai dari kerajaan & 4.03 & 3.81 & 3.74 & 3.86 \\
2 & Dapat bantuan makanan & 3.55 & 3.71 & 3.29 & 3.52 \\
3 & Dapat bantuan sewa rumah & 2.87 & 2.61 & 2.74 & 2.74 \\
4 & Dapat derma dari pihak luar & 2.83 & 3.23 & 2.87 & 2.98 \\
5 & Diskaun bil utiliti air \& elektrik & 3.77 & 3.77 & 3.45 & 3.67 \\
Jumlah (min) & 3.41 & 3.43 & 3.22 & 3.35 \\
Jumlah sampel (n) & 31 & 31 & 31 & 93 \\
\hline
\end{tabular}

Petunjuk: Rendah (1.00 sehingga 2.33), sederhana (2.34 sehingga 3.67), tinggi (3.68 sehingga 5.00) 
Selain bantuan berbentuk wang tunai, golongan B40 juga menerima bantuan dalam bentuk bekalan makanan, diskaun bil utiliti dan sewa rumah. Kakitangan swasta merupakan kumpulan yang paling tinggi (3.71) menerima bantuan bekalan makanan berbanding kakitangan kerajaan (3.55) dan kumpulan bekerja sendiri (3.29). Selain itu, sebahagian besar (3.77) daripada kakitangan kerajaan dan kakitangan swasta menerima diskaun bil utiliti (air dan elektrik). Responden yang bekerja sendiri merupakan kumpulan yang paling sedikit (3.45) menerima bantuan diskaun bil utiliti. Dapatan kajian ini juga menunjukkan tahap bantuan sewa rumah yang diperoleh oleh Golongan B40 adalah di tahap sederhana (2.74). Dapatlah dirumuskan bahawa bantuan kebajikan yang diterima untuk semua sektor secara keseluruhannya adalah di tahap yang sederhana (3.35).

\section{Perbincangan}

Tidak dapat disangkal bahawa perlaksanaan PKP menyebabkan sumber ekonomi golongan B40 terganggu terutamanya kepada kumpulan yang bekerja sendiri (rujuk Rajah 3). Perkara ini seiring dengan dapatan Jabatan Perangkaan Malaysia (2020) yang menyatakan bahawa kumpulan bekerja sendiri merupakan entiti yang paling terkesan mengalami pengurangan jumlah pendapatan khususnya bagi golongan B40 (Serina, 2020). International Labour Organization (2020) dan Estro (2020) juga bersetuju bahawa perlaksanaan MCO menyebabkan sektor ekonomi terganggu terutamanya kepada sektor ekonomi tidak formal yang sering dikaitkan dengan golongan bekerja sendiri. Ini kerana, berdasarkan proses temu bual yang dijalankan dalam kajian ini mendapati golongan bekerja sendiri sebahagian besarnya tidak dapat bekerja semasa perlaksanaan PKP terutamanya kepada pengusaha bas awam. Keadaan ini mewujudkan kes pengangguran sementara dalam skala yang besar seperti mana dinyatakan dalam kajian Kasim (2020). Antara lainnya juga, golongan bekerja sendiri merupakan kumpulan yang lebih rentan daripada aspek ekonomi kerana secara relatifnya mempunyai jumlah pendapatan yang lebih kecil berbanding golongan kakitangan swasta dan kakitangan kerajaan (rujuk Jadual 6).

Walaupun perlaksanaan PKP telah mengganggu sumber ekonomi golongan B40 khususnya bagi yang bekerja sendiri namun mereka tetap bersetuju PKP dilaksanakan (rujuk Jadual 3). Hal ini kerana, golongan tersebut beranggapan PKP tidak hanya mendatangkan impak negatif tapi juga memberi impak yang positif terutamanya daripada aspek keselamatan dan kesihatan serta aspek hubungan sosial (rujuk Jadual $4 \&$ Jadual 5). Golongan ini percaya bahawa dengan melaksanakan PKP selain dapat mengurangkan penularan virus COVID-19 juga memberi peluang untuk memperoleh rehat yang secukupnya (rujuk Jadual 4). Perkara ini selari dengan dapatan Nor Rohim dan Annissa (2020) iaitu dengan melaksanakan lockdown berjaya mengurangkan perebakan wabak Covid-19 di Jakarta. Naomie et al. (2020) juga mendapati jumlah kes jangkitan COVID-19 di Malaysia menunjukkan tren yang menurun semasa tempoh perlaksanaan PKP. Daripada aspek hubungan sosial pula golongan ini beranggapan dengan terlaksananya PKP, masa terluang yang lebih panjang mampu dimiliki bersama keluarga selain mengurangkan kadar jenayah setempat (rujuk Rajah 5). Hal yang serupa juga berlaku dalam konteks ruang lokasi yang lebih besar. Didapati indeks jenayah di seluruh negara menurun hampir 50 peratus sepanjang tempoh PKP dilaksanakan (Nor Azizah Mokhtar, 2020).

Meskipun begitu, perlaksanaan PKP haruslah lebih diperkemaskan terutamanya daripada aspek kebajikan. Ini kerana, tahap penerimaan bantuan kebajikan yang diterima berdasarkan sektor pekerjaan adalah tidak sama rata atau kurang seimbang. Kumpulan bekerja sendiri didapati kurang berpuas hati dengan bantuan yang diberikan semasa PKP berbanding dengan kumpulan kakitangan kerajaan dan swasta (rujuk Jadual 2). Hal ini disebabkan kumpulan bekerja sendiri merupakan golongan yang paling sedikit menerima bantuan tunai daripada pihak kerajaan berbanding dua sektor pekerjaan lainnya (rujuk Jadual 6). Selain itu, daripada aspek bantuan kebajikan dalam bentuk yang lain seperti diskaun bil utiliti, bantuan makanan dan sewa rumah juga secara puratanya menunjukkan nilai yang paling rendah (3.22) berbanding dua sektor pekerjaan yang lain (rujuk Jadual 6). Oleh hal demikian, pihak kerajaan haruslah menyalurkan lebih banyak bantuan kebajikan kepada kumpulan bekerja sendiri yang berstatus B40. Hal ini adalah seperti mana yang disarankan oleh Adli Amirullah yang merupakan Ahli Ekonomi Kanan Institut Demokrasi dan Hal Ehwal Ekonomi (IDEAS) (Mohd Zaky, 2020). 


\section{Kesimpulan}

Konklusinya, perlaksanaan PKP telah memberi impak yang serius kepada Golongan B40 khususnya di Bandaraya Kota Kinabalu. Impak yang dialami wujud dalam dua bentuk iaitu negatif dan positif. Impak negatif kesan perlaksanaan PKP dikaitkan dengan gangguan sumber ekonomi terutamanya kepada golongan bekerja sendiri manakala impak positif yang diperoleh pula adalah daripada aspek keselamatan, kesihatan dan hubungan sosial. Kesedaran yang tinggi terhadap peri pentingnya MCO dilakukan untuk mengekang penularan virus COVID-19 (aspek keselamatan) menyebabkan rata-rata Golongan B40 menyokong perlaksanaan PKP. Walau bagaimanapun, pihak kerajaan haruslah lebih peka dan prihatin terhadap aspek pengurusan kebajikan golongan B40 semasa PKP dijalankan. Hal ini kerana, wujudnya ketidakseimbangan daripada aspek penerimaan bantuan yang diperoleh berdasarkan sektor pekerjaan. Walhal, bantuan kebajikan yang diberikan dalam bentuk wang tunai, diskaun utiliti, bekalan makanan dan penurunan harga sewa rumah merupakan aspek penting kepada Golongan B40 untuk terus bertahan (survive) semasa PKP. Pemberian sumbangan yang lebih selaras kepada semua sektor pekerjaan amat penting untuk meminimumkan kesengsaraan golongan B40 khususnya daripada aspek ekonomi sepanjang tempoh PKP.

\section{Rujukan}

Ahmad Raflis Che Omar, Suraiya Ishak \& Mohd Abdullah Jusoh. (2020). The impact of Covid-19 Movement Control Order on SMEs' businesses and survival strategies. Geografia: Malaysian Journal of Society and Space, 16(2), 139-150.

Abdullah, A. H., Rahman, S. N. S. A., \& Hamzah, M. H. (2017). Metacognitive skills of Malaysian students in non-routine mathematical problem solving. Bolema - Mathematics Education Bulletin, 31(57), 310-322. https://doi.org/10.1590/1980-4415v31n57a15.

Bailey, A.B. (1978). Methods of Social Research. The Free Press London: Collin Mac Millan Publisher.

BH Online. (2020). COVID-19: Kes global melepasi angka 19 juta. Dipetik dari https://www.bharian.com.my/dunia/lain-lain/2020/08/718756/covid-19-kes-global-melepasiangka-19-juta pada 22 Ogos 2020.

Chamhuri Siwar, Mohd Khairi Ismail, Nurul Ashikin Alias \& Siti Zalikha Zahari. (2019). Kumpulan Isi Rumah Berpendapatan 40 Peratus Terendah (B40) Di Malaysia: Mengenal Pasti Trend, Ciri, Isu dan Cabaran. Dipetik dari https://www.researchgate.net/publication/338186730_Kumpulan_Isi_Rumah_Berpendapatan_40 Peratus Terendah B40 Di Malaysia Mengenal PastiTrend Ciri Isu Dan Cabaran pada 21 Ogos 2020.

Dickson, E., Baker, J., L., Hoornweg, D \& Tiwari, A. (2012). Urban Risk Assessments Understanding Disaster and Climate Risk in Cities. The World Bank 1818 H Street NW, Washington DC 20433, 3-8 DOI: 10.1596/978-0-8213-8962-1.

Dzulkifli, I. (2020). PKP: Peniaga kecil rayu bantuan kerajaan, Daily Express, 23 Mac 2020, Dipetik dari http://www.dailyexpress.com.my/news/149339/ pkp-peniaga-kecil-rayu-bantuan-kerajaan pada 25 Ogos 2020.

Er, A.c., Siti Shahidah, S., A. Habibah \& J. Hamzah. 2013. Impak Pembangunan Industri Petroleum Terhadap Kesejahteraan Hidup Penduduk Setempat di Paka, Terengganu. Akademika 83(1) 2013: 57-64.

Estro Dariatno Sihaloho. (2020). Dampak Covid-19 Terhadap Perekonomian Indonesia.DOI:10.13140/RG.2.2.13651.94241/1, https://www.researchgate.net/publication/34055426.

Fahim Aslam. (2020). COVID-19 and Importance of Social Distancing. Preprints (www.preprints.org), Dipetik dari DOI: $\quad$ 10.20944/preprints202004.0078.v1 pada 20 Ogos 2020.

Giallonardo., V, Sampogna., G, Del Vecchio., V, Luciano., M, Albert., U, Carmassi., C, Carra. G, Cirulli., F, Dell'Oss., B, Giulia Nanni., M, Pompili., M, Sani., Tortorella., A, Volpe., U \& Fiorillo. (2020). The Impact of Quarantine and Physical Distancing Following COVID-19 on Mental Health: Study Protocol of a Multicentric Italian Population Trial. STUDY 
DOI: https://doi.org/10.47405/mjssh.v6i9.999

PROTOCOL ARTICLE, Front. Psychiatry, 05 June 2020, Volume 11, Article 533, https://doi.org/10.3389/fpsyt.2020.00533

Ghani, F. A. (2020). Impak psikologi akibat wabak Covid-19, Astro Awani, 14 Mac 2020. Dipetik dari http://www.astroawani.com/beritamalaysia/ impak-psikologi-akibat-wabak-covid-19-233648 pada 23 Ogos 2020.

International Labour Organization. (2020). ILO Monitor: COVID-19 and the world of Work. Third edition Updated estimates and analysis. 29 April, 2020. https://ilostat.ilo.org/resources/methods/description-employment-by-status/.

Jabatan Perangkaan Malaysia. (2020). Newsletter. Diakses daripada www.dosm.gov.my pada 10 Ogos 2020.

Jabatan Perangkaan malaysia, Cawangan Sabah. (2007). Data Taburan Penduduk dan Jumlah Rumah mengikut Kampung Di Lembangan Sg. Menggatal.

Jabatan Perangkaan Malaysia, Negeri Sabah. (2015). Buku Tahunan Perangkaan Sabah 2014.

Jabatan Ukur dan Pemetaan Malaysia. (2011). Negeri Sabah Bahagian Pantai Barat Daerah Kota Kinabalu.

Jafar, A., Geogre, F., Mapa, M. T., Sakke, N., \& Dollah, R. (2021a). Perceptions Of Urban Poor With B40 Status On The Impact Of The Implementation Of Movement Control Order (Mco) By Employment Sector: A Case Study Of Kota Kinabalu City, Sabah. Journal Of Contemporary Issues In Business And Government, 27(2), 3603-3618.

Jafar, A., George, F., Meri, A., Chong, V. H., Mapa, M. T., Sakke, N., ... \& Baco, Z. (2021b). Keberkesanan Program Imunisasi COVID-19 Kebangsaan di Malaysia Timur. Malaysian Journal of Social Sciences and Humanities (MJSSH), 6(7), 1-11.

Jun She, Jinjun Jiang, Ling Ye, Lijuan Hu, Chunxue Bai \& Yuanlin Song. (2020). 2019 novel coronavirus of pneumonia in Wuhan, China: emerging attack and management strategies. Clicinal and Translational Medicine, https://doi.org/10.1186/s40169-020-00271-z.

Kasim Mansur. (2020). COVID-19 Impak Kepada Ekonomi dan Peranan Institusi Waqaf (endowment) Mendepani Kegawatan Sosio-ekonomi Ummah. Universiti Malaysia Sabah, http://eprints.ums.edu.my/id/eprint/25277.

Laman Rasmi Pejabat Perdana Menteri. 7 Jun 2020. Teks Ucapan Pelaksanaan Perintah Kawalan Pergerakan Pemulihan (PKPP). Diakses daripada https://www.pmo.gov.my pada 20 Ogos 2020.

Laporan Penyiasatan Perbelanjaan Isirumah (HES). 2016. Jabatan Statistik Malaysia (DOS).

Majlis Keselamatan Negara (2020). Kenyataan Media, 18 Mac 2020, Jabatan Perdana Menteri, Malaysia.

Mameli Peter. (2019). Natural Hazards: Pandemic Threats by Infectious Diseases. Public Management, John Jay College of Criminal Justice, New York, NY, USA, https://doi.org/10.1007/978-3-319-69891-5_205-1.

Mohd Shahrul Mohd Nadzir, Maggie Chel Gee Ooi, Kemal Maulana Alhasa, et al. (2020). The Impact of Movement Control Order (MCO) during Pandemic COVID-19 on Local Air Quality in an Urban Area of Klang Valley, Malaysia. Aerosol and Air Quality Research, 1-12, https://doi.org/10.4209/aaqr.2020.04.0163.

Mohd Zaky Zainuddin. 28 April (2020). BH Online. Salur lebih banyak bantuan kepada PKS, bekerja sendiri. Dipetik dari https://www.bharian.com.my/bisnes/pasaran/2020/04/682617/salurlebih-banyak-bantuan-kepada-pks-bekerja-sendiri pada 21 Ogos 2020.

Naomie Salim, Weng Howe Chan, Shuhaimi Mansor, Nor Erne Nazira Bazin, Safiya Amaran, Ahmad Athif Mohd Faudzi, Anazida Zainal, Sharin Hazlin Huspi, Eric Khoo Jiun Hooi \& Shaekh Mohammad Shithil. (2020). COVID-19 epidemic in Malaysia: Impact of lock-down on infection dynamics. Dipetik dari https://www.researchgate.net/publication/340591425_COVID19_epidemic_in_Malaysia_Impact_ of_lock-down_on_infection_dynamics, 10.1101/2020.04.08.20057463 pada 20 Ogos 2020 .

Newsletter Jabatan Perangkaan Malaysia. (2020). Kajian Kes Impak Perintah Kawalan Pergerakan Kepada Penduduk Malaysia. Jabatan Perangkaan Malaysia.

Nor Azizah Mokhtar. 6 Mei 2020. BH Online. Indeks jenayah turun hampir 50 peratus sepanjang PKP. Dipetik dari https://www.bharian.com.my/berita/kes/2020/05/685969/indeks-jenayahturun hampir-50-peratus-sepanjang-pkp pada 20 Ogos 2020. 
DOI: https://doi.org/10.47405/mjssh.v6i9.999

Nor Rohim Yunus \& Annissa Rezki. (2020). Kebijakan Pemberlakuan Lock Down Sebagai Antisipasi Penyebaran Corona Virus Covid-19. Jurnal Sosial dan Budaya Syar'i, Vol 7, N0 3 (2020), DOI: https://doi.org/10.15408/sjsbs.v73.15083

Noorazuan Md Hashim \& Shamsuddin. (2018). Tanggapan, Kesedaran Dan Motivasi Masyarakat Terhadap Penggunaan Air Hujan Sebagai Bekalan Alternatif Bandar. GEOGRAFIA OnlineTM Malaysian Journal of Society and Space, 14(3), 37 - 52, https://doi.org/10.17576/geo-2018-1403$\underline{04}$.

Noor Fzlinda Fabeil, Khairul Hanim Pazim \& Juliana Langgat. (2020). Strategi Kesinambungan Perniagaan Semasa Krisis Pandemik Covid-19: Kajian Rantaian Pengagihan Produk Pertanian Pekebun Kecil. 2nd Asnet International Multidisciplinary Academic Conference (AIMAC 2020) eISBN: 978-967-17837-3-3 Kuala Lumpur, Malaysia.

Perutusan Khas Perdana Menteri (2020). Ucapan Penuh Perutusan Khas Perdana Menteri Mengenai Covid-19, 10 April 2020, Dipetik dari https://www.pmo.gov.my/2020/04/perutusan-khasperdana-menteri-10-april-2020/ pada 25 Ogos 2020.

Puteri Marjan Megat Muzafar \& Theebalakshmi Kunasekaran. (2020). The Impact Of Covid-19 On The Urban Poor: Three Major Threats- Money, Food and Living Conditions. Khazanah Research Institute.

Rhyddhi Chakraborty. (2015). Epidemics. Encyclopedia of Global Bioethics DOI10, 1007/978-3-31905544-2_174-3, Springer Science Business Media Dordrecht 2015.

Serina Rahman. (2020). Overcoming the Odds and Filling the Gaps: Malaysian Civil Society Responses to COVID-19. ISEAS - Yusof Ishak Institute, 44.

Siti Maslina Abdul Rashid. (2020). PKP beri impak positif alam sekitar. Rencana, BH Online 5 Mei 2020.

Siti Zakiah Muhamad Isa. (2020). Newsletter. Jabatan Perangkaan Malaysia DOSM/BPPAS/Siri 18

Tarbotton. C., Dall'Osso. F., Dominey-Howes. D., Goff. J. (2015). The Use Of empirical Vulnerability Functions To Assess The Reaksise Of Buildings To Stunsmi Impact: Comparative Review and Summary Of Best Practice. Earth- Science Reviews 142 (2015) 120-134.

Utusan Borneo Online (2017). Jumlah penduduk Sabah kedua tertinggi. 31 Oktober 2017. Dipetik dari https://www.utusanborneo.com.my/2017/10/31/jumlah-penduduk-sabah-kedua-tertinggi pada 13 September 2020.

Viratna Sujarweni V. (2015). SPSS Untuk Penelitian. Pustaka Baru Press, Bantul, Yogyakarta.

World Health Organisation (2019). Coronavirus disease (Covid-2019) situation reports. Dipetik dari from https://www.who.int/emergencies/diseases/novel-coronavirus-2019/situation-reports pada 23 Ogos 2020.

Wika Ristya. (2012). Kerentanan Wilayah Terhadap banjir Di Sebahagian Cekungan Bandung. Universitas Indonesia (Tesis Sarjana). 